\title{
IMPLEMENTASI BRAIN GYM DALAM UPAYA MENINGKATKAN KONSENTRASI ANAK ASPERGER SYNDROME DI SEKOLAH BERKEBUTUHAN KHUSUS BANGUN BANGSA SURABAYA
}

\author{
Partiwi Ngayuningtyas Adi \\ IKIP PGRI Jember \\ Partiwiplb.ikip@gmail.com
}

\begin{abstract}
Abstrak
Latar belakang dari penelitian ini adalah kesulitan konsentrasi yang sering dijumpai pada siswa asperger syndrome. Rumusan masalah dalam penelitian ini adalah bagaimana implementasi brain gym dalam upaya meningkatkan konsentrasi anak asperger syndrome di Sekolah Berkebutuhan Khusus Bangun Bangsa Surabaya. Tujuan penelitian ini adalah meningkatkan konsentrasi anak asperger syndrome melalui metode brain gym. Penelitian ini termasuk dalam kategori penelitian SSR (subyek single research) atau dalam bahasa indonesianya adalah penelitian subyek tunggal. Penelitian ini dilakukan di Sekolah Berkebutuhan Khusus Bangun Bangsa Surabaya. Sasaran dalam penelitian ini adalah siswa asperger syndrome kelas 3 SD. Hasil penelitian menunjukan terjadi peningkatan konsentrasi anak. Konsentrasi anak mengalami perubahan kecenderungan arah positif, perubahan kecenderungan dari tidak stabil menjadi stabil, leverl perubahan meningkat menjadi 20-40 point dan overlap data $12,5 \%$. Berdasarkan penelitian dapat disimpulkan bahwa metode brain gym dapat meningkatkan konsentrasi anak asperger syndrome.
\end{abstract}

Kata kunci: brain gym, konsentrasi, asperger syndrome

\section{PENDAHULUAN}

Asperger syndrome adalah salah satu anak berkebutuhan khusus yang memiliki hambatan dalam membentuk konsentrasi. Kesulitan berkonsentrasi merupakan salah satu gangguan yang sering dijumpai pada anak asperger syndrome. Gangguan konsentrasi pada anak asperger syndrome dapat mengganggu anak asperger syndrome dalam melaksanakan proses belajar dikelas. Gangguan konsentrasi dapat menyebabkan anak asperger syndrome mengalami kesulitan dalam menerima informasi dan materi dari guru. Dalam penelitian ini peneliti mengambil sampel 5 anak asperger syndrome di Sekolah Bangun Bangsa Surabaya. Berdasarkan pendahuluan penelitian yang dilakukan di sekolah berkebutuhan khusus bangun bangsa Surabaya, peneliti menemukan 5 anak asperger syndrome dan mereka mengalami gangguan dalam berkonsentrasi. Mereka hanya mampu berkonsentrasi kurang http://doi.org/10.31537/speed.v3i2.277 dari 1 menit. Mereka berada di kelas 3 SD dengan usia sekitar 9-10 tahun. Dari latar belakang tersebut peneliti ingin mengembangkan metode brain gym untuk meningkatkan konsentrasi anak asperger syndrome. Berdasarkan fenomena diatas maka peneliti mengambil judul, "IMPLEMENTASI BRAIN GYM DALAM UPAYA MENINGKATKAN KONSENTRASI ANAK ASPERGER SYNDROME DI SEKOLAH BERKEBUTUHAN KHUSUS BANGUN BANGSA". Rumusan masalah dalam penelitian ini adalah bagaimana implementasi brain gym dalam upaya meningkatkan konsentrasi anak asperger syndrome di Sekolah Berkebutuhan Khusus Bangun Bangsa Surabaya. Tujuan penelitian ini adalah meningkatkan konsentrasi anak asperger syndrome melalui metode brain gym.

Sindrom Asperger (bahasa Inggris: Asperger syndrome, Asperger's syndrome, Asperger's disorder, 
Asperger's atau AS) adalah salah satu gejala autisme di mana para penderitanya memiliki kesulitan dalam berkomunikasi dengan lingkungannya, sehingga kurang begitu diterima (Wikipedia, 2018). Anak-anak dengan Asperger's syndrome umumnya mempunyai kecerdasan normal. Dan meskipun mereka kemungkinan mengalami gangguan berkomunikasi setelah dewasa, anak dengan Asperger's syndrome cenderung mempunyai perkembangan bahasa yang mendekati normal. Anak asperger syndrome terkadang memiliki pergerakan yang melibatkan tubuh seperti olahraga. Asperger Syndrome memiliki gejala hampir sama dengan autis, yakni anak mengalami kekurangan dalam interaksi sosial dan komunikasi namun tidak mengalami kelambatan dalam bicara dan berbahasa, perkembangan kognitif, ketrampilan menolong diri sendiri atau rasa ingin tahu terhadap dunia luar. Penyebab dari anak asperger syndrome adalah factor genetic dan non genetic. Seseorang Sindrom Asperger dapat memperlihatkan bermacam-macam karakter dan gangguan. Ciri-ciri dari anak asperger syndrome adalah sulit mengadakan komunikasi 2 arah, kesulitan dalam berinteraksi, sering berbicara yang berulang, obsesi dengan topic yang komplek, kesulitan dalam pelajaran matematika,membaca dan menulis, gerakan canggung, memiliki perilaku yang aneh. Ketika orang berbicara, umumnya mereka menggunakan bahasa tubuh seperti senyuman dan komunikasi nonverbal lainnya, dan juga kata-kata yang dikeluarkan oleh mereka cenderung memiliki lebih dari satu buah makna. Definisi dari konsentrasi belajar adalah pemusatan daya pikiran dan perbuatan pada suatu obyek yang dipelajari dengan menghalau dan menyisihkan segala obyek yang tidak ada hubungannya dengan obyek dipelajari. Sedangkan menurut buku besar bahasa Indonesia konsentrasi adalah pemusatan perhatian dan pemikiran pada suatu hal. Menurut Singgih (2008) konsentrasi merupakan suatu proses yang mengarahkan kesadaran sehingga dapat menggunakan fungsi indera dengan baik terhadap suatu yang dihadapi. Sebagian besar anak asperger syndrome sering mengalami hambatan dalam berkonsentrasi atau pemusatan perhatian, perhatian mudah terallihkan, sulit dalam memperhatikan instruksi, dalam mengerjakan tugas, sering bingung dalam memperhatikan, dan sering mengalami kesulitan memusatkan perhatian terhadap tugas atau permainan. Konsentrasi adalah kemampuan anak dalam mencerminkan kegiatan sehari-hari. Dalam menjalankan pekerjaan konsentrasi adalah menjadi syarat utama. Konsentrasi yang baik adalah salah satu factor utama dalam anak memperoleh keberhasilan belajar di sekolah. Sugiyanto (Helmi, 1995) mengemukakan bahwa definisi dari konsentrasi adalah kemampuan dalam memusatkan pemikiran atau kemampuan mental dalam menyortir informasi yang tidak dibutuhkan dan memusatkan perhatian hanya pada informasi yang dibutuhkan. Salah satu program komersial yang terpopuler di 80 negara lebih adalah brain gym. Brain gym dapat dipercaya memberikan stimulasi sangat dibutuhkan untuk pembelajaran yang efektif. Menurut hasil penelitian yang dilakukan oleh Ayinosa (2009) brain gym dalam olahraga dan latihan, dapat meningkatkan konsentrasi, atensi, kewaspadaan dan kemampuan fungsi otak untuk melakukan perencanaan, respond dan membuat keputusan. Menurut Yanuarita (2012, hlm. 77) Brain Gym bermanfaat untuk anak 
dengan gangguan hiperaktif, kerusakan otak, sulit konsentrasi dan depresi. Salah satu gerakan brain gym yang meningkatkan konsentrasi anak adalah gerakan sakelar otak, gerakan ini dapat mengoptimalkan pengiriman pesan dari otak kiri keotak kanan dan sebaliknya, meningkatkan penerimaan oksigen dan stimulasi aliran darah agar lancar ke otak, gerakan tombol imbang dapat meningkatkan konsentrasi, pengambilan keputusan, pemikiran asosiatif, kepekaan indrawi untuk keseimbangan dan lain-lain. Yanuarita (2012) menambahkan bahwa gerakan pasang kuda-kuda dapat membantu berkonsentrasi dan membantu mengingat pelajaran yang didapat. Gerakan brain gym dapat mengaktifkan otak pada tiga dimensi yaitu lateralitaskomunikasi, pemfokusan-pemahaman, dan pemusatan-pengaturan. Dalam melaksanakan brain gym ini frekuensi yang tepat adalah seminggu 3 kali, sekali latihan sekitar 10-15 menit. Dalam penelitian ini gerakan brain gym yang dilakukan adalah sakelar otak. Cara melakukan gerakan sakelar otak adalah jaringan lunak dibawah tulang selangka dikiri dan kanan tulang dada, dipijat dengan satu tangan, sementara tangan yang lain memegang pusar. Fungsi dalam latihan ini adalah tingkat energy lebih baik, keseimbangan tubuh kanan dan kiri, memperbaiki kerjasama kedua mata, otot tengkuk dan bahu lebih rileks. Otot-otot yang dilatih dalam gerakan sakelar adalah deltoid, Triceps brachii, Biceps brachii.

\section{METODE}

Penelitian ini menggunakan jenis penelitian eksperimental. Penelitian ini termasuk dalam kategori penelitian SSR (subyek single research) atau dalam bahasa indonesianya adalah penelitian subyek tunggal. Penelitian ini dilakukan di Sekolah Berkebutuhan Khusus Bangun Bangsa Surabaya. Sasaran http://doi.org/10.31537/speed.v3i2.277 dalam penelitian ini adalah siswa asperger syndrome kelas $3 \mathrm{SD}$ di Sekolah Berkebutuhan Khusus Bangun Bangsa Surabaya. Jumlah sample siswa dalam penelitian ini adalah 5 siswa. Penelitian ini dilakukan selama 10 pertemuan dengan rincian 5 pertemuan untuk baseline dan 5 pertemuan untuk intervensi. Setiap sesi pengamatan dilakukan selama 60 menit. Desain yang digunakan dalam penelitian ini adalah desain A-B, dimana A merupakan phase baseline (sebelum diberikan intervensi), dan B merupakan phase intervensi (pada saat pemberian perlakuan). Dalam desain A-B dilakukan dengan 2 tahapan, tahap pertama dilakukan dengan melihat konsentrasi awal anak dalam mengikuti pembelajaran dan tahap kedua dilakukan dengan kemampuan konsentrasi anak saat mendapatkan intervensi (brain gym). Penelitian ini memiliki 2 variabel yaitu variabel bebas dan variabel terikat. Variabel bebas dalam penelitian ini adalah brain gym sedangkan terikat dalam penelitian ini adalah kemampuan konsentrasi. Pengumpulan data menggunakan pencatatan dengan observasi langsung serta pengumpulan variabel dengan menggunakan durasi. Peneliti menguukur durasi kemampuan konsentrasi anak. Data pada penelitian ini dipresentasikan dengan menggunakan grafik garis. Dalam analisis data penelitian ini menggunakan metode analisis visual yaitu analisis dalam kondisi dan analisis antar kondisi.

\section{HASIL DAN PEMBAHASAN}

Penelitian ini menggunakan metode brain gym dengan subyek penelitian tunggal atau single subyek research (SSR). Teknik pengumpulan data dilakukan dengan pengamatan konsentrasi anak. Pada saat melakukan observasi awal siswa kelas 3 SD 
asperger syndrome di Sekolah Bangun Bangsa Surabaya, peneliti melihat kesulitan siswa dalam berkonsentrasi sehingga siswa kurang maksimal dalam mengikuti materi pelajaran yang diberika oleh guru.

Hasil penelitian menunjukan terjadi peningkatan konsentrasi anak. Konsentrasi anak mengalami perubahan kecenderungan arah positif, perubahan kecenderungan dari tidak stabil menjadi stabil, leverl perubahan meningkat menjadi 20-40 point dan overlap data $12,5 \%$. Rincian level perubahan siswa adalah siswa A 40 point, siswa B 30 point, siswa C 20 point, siswa D 40 point dan siswa E 30 point. Hasil terendah yaitu pada siswa C 20 point, hal ini dikarenakan perilaku tantrum yang sering timbul pada siswa di kelas. Hasil Pada analisis data telah dibuktikan bahwa ada peningkatan yang signifikasn terhadap konsentrasi 5 siswa Sekolah Bangun Bangsa Surabaya melalui brain gym pada 5 sesi yang diberikan. Berdasarkan penelitian diatas dapat disimpulkan bahwa konsentrasi anak asperger syndrome dapat ditingkatkan melalui penanganan yang tepat. Dari hasil data pengamatan konsentrasi menunjukan bahwa brain gym sangat diperlukan untuk meningkatkan konsentrasi anak asperger syndrome. Sebelum melakukan penelitian, peneliti melakukan pendekatan pada siswa. Awal melakukan penelitian 3 anak sulit dikondisikan di kelas, mereka semau sendiri bahkan satu anak tantrum di kelas, hal ini dikarenakan kehadiran peneliti sebagai orang baru (adaptasi siswa terhadap orang baru). Namun pada sesi-sesi berikutnya siswa mulai dapat beradaptasi dengan peneliti dan peneliti mulai dapat mengendalikan siswa dikelas.

\section{PENUTUP}

\section{Simpulan}

http://doi.org/10.31537/speed.v3i2.277
Penelitian ini menerapkan metode brain gym. Gerakan brain gym pada penelitian ini adalah sakelar. Metode brain gym dalam penelitian ini digunakan untuk meningkatkan konsentrasi anak. Peningkatan konsentrasi anak dapat membantu anak dalam menjalankan pembelajaran dikelas. Sample pada penelitian ini berjumlah 5 siswa asperger syndrome dengan karakteristik utama gangguan konsentrasi. Penelitian dilaksanakan di Sekolah Berkebutuhan Khusus Bangun Bangsa.

\section{Saran}

Saran untuk peneliti selanjutnya adalah brain gym dapat diterapkan pada anak berkebutuhan khusus yang lain,tidak hanya pada siswa asperger syndrome. Penerapan brain gym pada ABK harus disesuaikan dengan karakteristik dan kebutuhan anak.

\section{DAFTAR PUSTAKA}

American of Pediatrics, Committee on Children With Disabilities.Technical Report : The Pediatrician's Role in Diagnosis and Management of Autistic Spectrum Disorder in Children. Pediatrics

Anderson S, Romanczyk R. (1999). Earl intervention for young children withautism: $A$ continuum-based behavioral models. JASH

Baihaqi, M dan Sugirman, M. (2006) Memahami dan Membantu Anak $A D H D$. Bandung: PT. Refika Aditama

Brain Gym Internasional, 2008. Diakses 20 February 2018, dari http://braingym.org/studies 
Dennison, P.E (2008). Brain Gym. PT Gramedia: Jakarta.

Yanuarita, A. (2012). Memaksimalkan Otak Melalui Senam Otak (Brain Gym), Jogjakarta: Teranova. 